ZBIGNIEW ZioŁo

Akademia Pedagogiczna, Kraków

\title{
Problematyka badawcza efektów restrukturyzacji polskiej przestrzeni przemyslowej
}

Wytyczanie racjonalnych kierunków rozwoju działalności przemysłowej w globalizującej się gospodarce światowej, która generuje nasilające się procesy integracji europejskiej, wymaga podejmowania całościowych studiów diagnostycznych, określających dotychczasowe uwarunkowania i ich wpływ na generowanie czynników rozwoju oraz kształtowanie się pod ich wpływem procesów przemian. Pozwalają one na przewidywanie zmian warunków otoczenia oraz na określanie celów, a także kreowania odpowiednich instrumentów, które wpływać będą na pobudzanie racjonalnych działań na rzecz realizacji założonej strategii rozwoju.

Podejmując problematykę badania efektów restrukturyzacji polskiej przestrzeni przemysłowej przyjmujemy, iż na przełomie XX i XXI pojawiły się nowe wyzwania cywilizacyjne związane z przejściem z industrialnej fazy rozwoju poprzez fazę postindustrialną do informacyjnej fazy rozwoju. Zmieniły one uwarunkowania rozwoju przemysłu od skali globalnej po skalę regionalną, a także wpłynęły na zmianę jego funkcji w rozwoju gospodarczym oraz na konieczność przebudowy dotychczasowych struktur branżowych. Wpływa to w zasadniczym stopniu na zmianę bazy ekonomicznej mającej podstawowe znaczenie dla rozwoju cywilizacyjnego poszczególnych obszarów. Podczas gdy w fazie industrialnej podstawową bazę ekonomiczną stanowił przemysł, w fazie postindustrialnej - działalność usługowa, to $\mathrm{w}$ fazie informacyjnej bazę stanowi nauka.

W przestrzeni geograficznej [Zioło 1996, 1997, 1999] występują bardzo zróżnicowane warunki dla wchłaniania innowacyjnych czynników rozwoju przemysłu oraz związanego z nimi wzrostu gospodarczego. Wyrazem tego jest fakt, iż w przestrzeni światowej znaczna część obszarów znajduje się jeszcze w warunkach rozwoju feudalnego, gdzie bazę ekonomiczną stanowi rolnictwo, a także w fazie rozwoju industrialnego czy postindustrialnego, a tylko nieznaczna część obszaru światowego znajduje się w informacyjnej fazie rozwoju*. Stwarza to odmienne uwarunkowania dla procesów rozwoju przemysłu oraz rozwoju społeczno-gospodarczego i kulturowego ludności poszczególnych obszarów.

* Zmiany uwarunkowań i tendencji rozwoju działalności przemysłowej wyraża także tzw. narastanie fal wyróżnione przez Schumpetera, które obejmują: pierwsza fala - energia wodna, tekstylia, żelazo, trwająca 60 lat od 1785 do 1845; druga fala - energia parowa, kolej, stal, trwająca 55 lat od 1845 do 1900; trzecia fala - elektryczność, chemikalia, silnik spalinowy, trwająca 50 lat od 1900 do 1950; czwarta fala - petrochemia, elektronika, lotnictwo, trwająca 40 lat, od 1950 do 1990; piąta fala - sieci cyfrowe, software, nowe media, która może trwać 30 lat od 1990 do 2020 . 
W warunkach krajowych, w fazie industrialnej przemysł traktowany był jako wiodący czynnik intensyfikujący wzrost i przemiany struktur przestrzennych [Dobrowolska 1978; Zioło 1980]. Przemysł traktowany był wówczas jako podstawa bazy ekonomicznej i w zasadniczym stopniu wpływał na rozmiary rynku pracy, a liczba zatrudnionych przyjmowana była jako podstawowy miernik potencjału przemysłowego [Pakuła, Troc 1987; Misztal, Zioło (red.) 1998]. W miarę rozwoju technicznego wprowadzano nowe mierniki odnoszące się do: wartości produkcji i środków trwałych, mocy zainstalowanych urządzeń odbiorczych i zużycia energii elektrycznej [Zioło 1972, 1973].

W fazie postindustrialnej nastąpiły istotne zmiany w rozwoju przemysłu i gospodarki światowej. Przejawiają się one w tendencji do zahamowania wcześniejszego stałego wzrostu udziału przemysłu w całości zatrudnienia w gospodarce narodowej. Np. w USA w 1920 r. w przemyśle pracowało ok. 30\%, w 1950 już ok. 25\%, w 1985 ok. 17\%; przewiduje się, że w 2010 będzie to ok. 10\%, a w 2050 już tylko ok. 3\% [Karpiński 1994; Karpiński i in. 1999]. Obecnie w przemyśle krajów rozwiniętych zaznacza się trend do dalszego spadku zatrudnienia, co jednak nie będzie powodować spadku produkcji. Postępująca eliminacja czynnika ludzkiego z produkcji przemysłowej wynika bowiem z szybkiego rozwoju postępu technologicznego, który przejawia się w automatyzacji i robotyzacji produkcji. W przyszłości doprowadzi do tego, że człowiek wcale nie będzie wykonywał ciężkiej pracy fizycznej. Automatyzacja i robotyzacja znacznie obniża koszty produkcji, poprzez wzrost wydajności oraz precyzyjniejsze wykonanie wielu prac, np. spawalniczych, czyniąc ją bardziej konkurencyjną na rynkach.

W fazie informacyjnej zmniejsza się więc rola przemysłu i usług jako bazy ekonomicznej i rynku pracy, a zwiększa się znaczenie nauki, na której opiera się gospodarka i dalszy wzrost działalności przemysłowej i usługowej. Do tych tendencji musi dostosować się także gospodarka krajowa, w której w coraz większym stopniu podstawowe znaczenie będzie odgrywać gospodarka oparta na wiedzy [Kukliński (red.) 1995, 2001].

W nowych uwarunkowaniach gospodarowania, związanych z przyjmowaniem reguł gospodarki rynkowej, uruchomione zostały procesy restrukturyzacji polskiego przemysłu. Ta złożona problematyka była przedmiotem badań w krajowych ośrodkach geograficznych oraz była prezentowana i dyskutowana na wielu konferencjach Komisji Geografii Przemysłu Polskiego Towarzystwa Geograficznego, a wyniki ich publikowane w serii prac komisji*. Dotychczasowe prace badawcze związane z postępującymi procesami restrukturyzacji wskazują na różnorodne aspekty tego bardzo złożonego procesu społecznego, gospodarczego i kulturowego, który wpływa na zmiany zachowań przedsiębiorstw i związanych z nimi przemysłowych układów przestrzennych (form koncentracji przemysłu, takich jak: przemysł rozproszony, skupienia, ośrodki, okręgi, kompleksy przemysłowe czy wyróżniane obszary przemysłowe), a także krajowej przestrzeni przemysłowej.

W świetle przedstawionych przesłanek należy przyjąć, iż problematyka badawcza efektów restrukturyzacji polskiej przestrzeni przemysłowej nabiera coraz większego znaczenia i powinna się nadal intensywnie rozwijać. Wynika to z faktu, iż wobec postępującej specjalizacji i zawężania pól badawczych na gruncie nauk ekonomicznych w zakresie problematyki przemysłu [Borowiecki (red.) 1998, 1999, 2000; Stabryła (red.) 2000], konieczne są prace obejmujące całościowe analizy przedsiębiorstw, a także wybranych układów przestrzennych.

Analizując problematykę efektów restrukturyzacji polskiej przestrzeni przemysłowej należy przyjąć, że:

"Do tej pory ukazało się 20 tomów, w tym 8 w nowej serii „Prace Komisji Geografii Przemysłu”. 
- zakład przemysłowy (przedsiębiorstwo, firma) są podstawowymi elementami struktury przestrzennej przemysłu,

- skupienia przestrzenne zakładów przemysłowych tworzą - w zależności od wielkości potencjału i złożoności struktury branżowej, powiązań organizacyjno-produkcyjnych i innych - określone formy koncentracji przemysłu (przemysł rozproszony, skupienia przemysłowe, ośrodki przemysłowe, okręgi przemysłowe, kompleksy przemysłowe) czy obszary o różnym stopniu uprzemysłowienia [Zioło (red.) 1988; 1990; 1993],

- wymienione formy koncentracji przestrzennej przemysłu tworzą bardziej złożoną strukturę przestrzenną przemysłu regionalnego, makroregionalnego czy krajowego, która jest elementem podprzestrzeni społeczno-gospodarczej, a także częścią przestrzeni geograficznej.

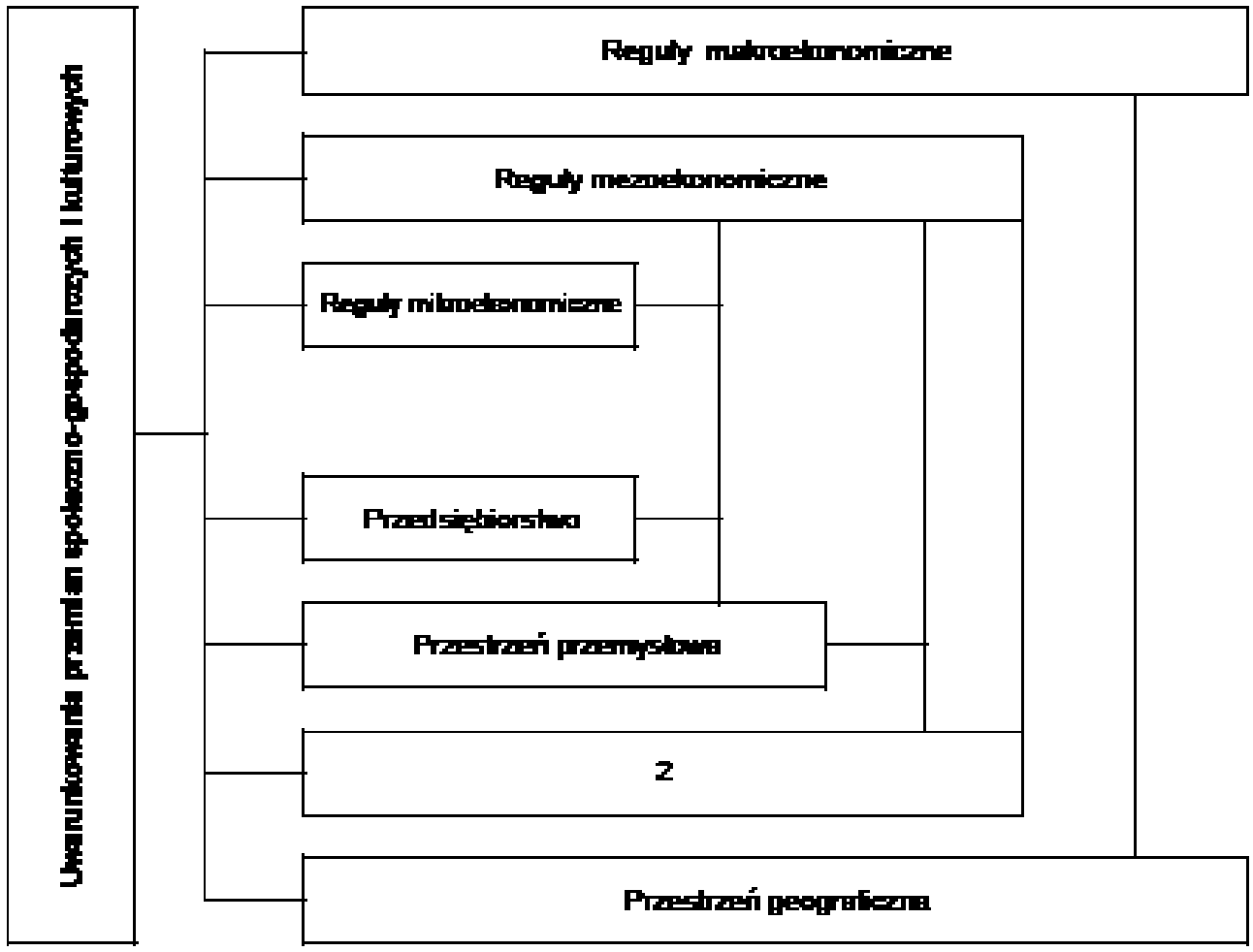

Ryc. 1. Wpływ reguł rozwoju na przemiany przemysłu

Źródło: Opracowanie własne

W podejmowaniu problematyki efektów restrukturyzacji przemysłu należy przyjąć, iż wyróżnione układy przemysłowe kształtują się pod wpływem określonych reguł i odpowiednich uwarunkowań (ryc. 1). Efekty restrukturyzacji przemysłu wiążą się z przyjmowaniem określonych zasad, wynikających z prawidłowości kształtowania się procesów 
w skali makro-, mezo- oraz mikroekonomicznej, które mają charakter aprzestrzenny i niekiedy w różnym stopniu oddziałują na kierunki rozwoju przestrzeni społeczno-gospodarczej, przestrzeni przemysłowej oraz poszczególnych przedsiębiorstw, zróżnicowanych pod względem potencjału, reprezentowanej branży, powiązań kapitałowo-produkcyjnych i rynkowych. Problematykę tę można precyzyjniej analizować badając zachodzące między nimi relacje, np. w jakim stopniu reguły makroekonomiczne wpływają na przestrzeń geograficzną $\left[\mathrm{O}^{\mathrm{p}}\right]$, czy wpływ reguł mikroekonomicznych na kształtowanie się przedsiębiorstwa i przestrzeni przemysłowej (tab. 1). Znaczną rolę w tym zakresie odgrywają także zmiany uwarunkowań przestrzennych, które wynikają z określonego poziomu rozwoju i zaznaczających się kierunków przemian społeczno-gospodarczych i kulturowych. Nakładające się procesy ekonomiczne na zróżnicowane uwarunkowania przestrzenne dają często odmienne efekty, zaznaczające się zarówno w układzie europejskim, jak i w uwarunkowaniach krajowych, regionalnych i lokalnych [Zioło 1996]. Wyrazem tego jest określona pozycja konkurencyjna krajowych układów regionalnych [Kudełko 2005, 2002]. Dlatego ważnym problemem badawczym są efekty wpływu zarówno prawidłowości zachowania przemysłu jako całości, a także prawidłowości zachowań odnoszących się do zróżnicowanych branżowo przedsiębiorstw, występujących w określonych uwarunkowaniach układu lokalnego [Rachwał 2004; Antoniewicz, Kulikowski (red.) 2004].

Tabela 1. Relacje między regułami przemian ekonomicznych a kategoriami przestrzeni geograficznej

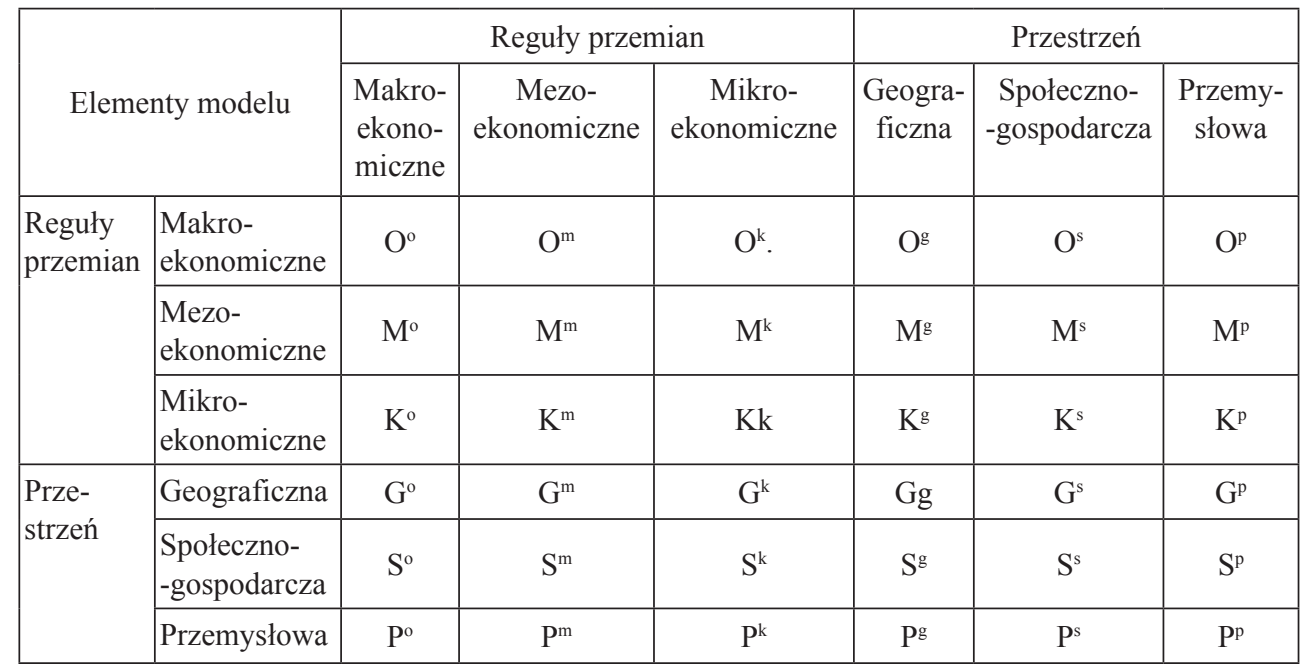

Źródło: Opracowanie własne

W badaniach efektów restrukturyzacji przemysłu bardzo ważne jest określenie zmian uwarunkowań działalności przedsiębiorstw przemysłowych związanych z procesami:

- globalizacji, wywodzącymi się z prawa postępującej koncentracji kapitału,

- integracji europejskiej, które tworzą nową europejską przestrzeń polityczną, gospodarczą, społeczną i kulturową,

- transformacji gospodarki krajowej związanej z wdrażaniem reguł gospodarki rynkowej, 
- transformacji układów regionalnych oraz kształtowaniem się nowych struktur branżowych.

Równocześnie postępujący rozwój cywilizacyjny stawia nowe wyzwania, które dynamizują różnorodne relacje i wprowadzają do określonych zmiany ilościowo-jakościowe.

W wyniku zmian zarysowanych relacji zmieniają się zachowania poszczególnych przedsiębiorstw oraz elementów ich otoczenia. W efekcie tego procesu poszczególne przedsiębiorstwa przemysłowe mogą zachowywać się jako elementy [Zioło 1980, 1986]:

- zanikłe,

- zanikające,

- stagnujące,

- rozwijające się,

- nowo pojawiające się [Zioło 2001, 2004].

W analizie efektów restrukturyzacji przestrzeni przemysłowej ważnym zagadnieniem są zmiany nie tylko zachowań przedsiębiorstw przemysłowych, ale związanych z nimi układów przestrzennych (np. ośrodków przemysłowych czy okręgów), które w wyniku nakładanych i selektywne działających czynników w różnym stopniu wpływają na zachowanie się poszczególnych przedsiębiorstw (zakładów), pobudzają w nich procesy wzrostu ilościowego lub przemian ilościowo-jakościowych, a całość danego układu może prowadzić do ich recesji, stagnacji lub rozwoju.

W badaniu efektów restrukturyzacji ważnym zagadnieniem są zmiany struktur własnościowych, przejawiających się w określonym stopniu prywatyzacji przedsiębiorstw. Zachodzi przy tym pytanie, w jakim stopniu prywatyzacja wpłynęła na zmiany potencjału produkcyjnego poszczególnych przedsiębiorstw, unowocześnienie asortymentu produkcji, podniesienie ich konkurencyjności oraz zmiany profilu działalności.

Przy określaniu efektów restrukturyzacji ważnym zagadnieniem jest powiązanie przedsiębiorstw krajowych z kapitałem zagranicznym poprzez bezpośrednie inwestycje lub zasilanie finansowe istniejących przedsiębiorstw przemysłowych [Stryjakiewicz 1999; Domański 2001; Olesiński (red.) 1998; Kudełko 1996, 1997; Bojar 2001], a także ich powiązań funkcjonalnych w strukturze firm światowych: wpływ nowego właściciela na zachowanie przedsiębiorstw, zmiany technologiczne, miejsce w układzie produkcyjno-logistycznym korporacji, rozmiar produkcji.

Szczególnie ważnym zagadnieniem jest dokonywanie pomiaru zachodzących zmian oraz dobór odpowiednich mierników, które charakteryzują istotne aspekty funkcjonowania przedsiębiorstw i związanych z nimi układów przestrzennych.

Przez wiele lat w pracach z zakresu geografii przemysłu miernikiem określającym wielkość przemysłu była liczba zatrudnionych. Wynikało to głównie z dostępności do porównywanej bazy statystycznej oraz znacznego udziału pracy ludzkiej w procesach wytwórczych.

W miarę wzrostu mechanizacji, a obecnie postępującej robotyzacji ważnym zagadnieniem w analizach przedsiębiorstw przemysłowych, a także struktur przemysłowych jest dobór określonych mierników [Zioło 1972, 1973], które określają różnorodne aspekty ich funkcjonowania i rozwoju. A oto one:

- miernik potencjału przemysłowego: wartość rynkowa (wartość akcji), liczba stanowisk pracy (liczba pracujących na największej zmianie), moc zainstalowanych urządzeń odbiorczych, wyposażenie techniczne,

* Szczególne ważne są tu przedsiębiorstwa związane z tzw. wysokimi technologiami oraz nasilaniem się procesów informatyzacji przestrzeni. 
- miernik pracy przedsiębiorstw: liczba zatrudnionych, stopień wykorzystania potencjału produkcyjnego (np. zmianowość, czas pracy, stopień wykorzystania czasu pracy),

- miernik ekonomicznej działalności: wartość sprzedaży, przychodów, dochodów, zysku, eksportu, produkcji na rynek krajowy i inne.

Na podstawie wartości poszczególnych mierników można budować różnorodne wskaźniki, które są ilorazami przyjętych wartości mierników empirycznych, np. wydajności pracy (wartość sprzedaży na jednego zatrudnionego, czy pracującego), stopnia wyposażenia technicznego (wartość środków trwałych na zatrudnionego na największej zmianie), stopnia wykorzystania majątku i inne.

W warunkach zmian systemu gospodarowania ważną rolę odgrywają mierniki określające efekty restrukturyzacji układów przestrzennych - dokonanych w danym przekroju czasowym, które dotyczą zmian:

- struktur własnościowych,

- potencjału produkcji, w świetle określonych mierników i wskaźników,

- stopnia koncentracji: przestrzennej w odniesieniu do powierzchni (koncentracja terytorialna), ludności (koncentracja demograficzna), ekonomiczna (w stosunku do np. PKB, dochodów jednostek samorządowych, liczby pracujących ogółem czy pracujących w danym sektorze), innych wybranych cech społeczno-gospodarczych,

- stopnia specjalizacji przemysłu, wskazującego na stabilność wykształconej wcześniej struktury lub jej zmienność,

- stopnia redystrybucji: przestrzennej, gałęziowej, wielkościowej i innej.

Procesowi temu towarzyszą poważne zmiany:

- oddziaływania przedsiębiorstwa na otoczenie: lokalne, ponadregionalne, subregionalne, regionalne, krajowe, zachodnioeuropejskie, środkowoeuropejskie, wschodnioeuropejskie, światowe, w tym krajów ekonomicznie rozwiniętych, krajów rozwijających się (strefy Pacyfiku), krajów zapóźnionych w rozwoju,

- w zakresie powiązań aktywnych i pasywnych: surowcowych, kooperacyjnych, rynkowych, kapitałowo-finansowych, technologicznych, informacyjnych, organizacyjnych i zarządzania.

Dla analizy efektów restrukturyzacji układów przestrzennych, od układów lokalnych, poprzez układy regionalne po układ krajowy, ważnym zagadnieniem jest określenie stopnia przebudowy industrialnej bazy ekonomicznej poprzez dokonujące się przekształcania:

- przestrzennych struktur przemysłowych, np. przemysłu rozproszonego, skupień przemysłowych, ośrodków przemysłowych, okręgów przemysłowych, obszarów przemysłowych,

- relacji powiązań sieciowych w zakresie: zarządzania, powiązań kooperacyjnych, rynkowych, kapitałowych, technologicznych i innych.

Wstępnie można przyjąć, iż podstawowa przesłanka badań efektów restrukturyzacji przestrzeni przemysłowej wynika z chęci określenia: dotychczasowych tendencji rozwoju przemysłu, możliwości jego dalszego rozwoju w warunkach postępującej globalizacji, oceny stopnia atrakcyjności danego układu przestrzennego w zakresie przyciagania zewnętrznych i generowania wewnętrznych czynników rozwoju, wypracowanie nowych celów rozwojowych oraz kreowanie odpowiednich instrumentów, podnoszących ich konkurencyjność w układzie światowym, europejskim czy krajowym.

Reasumując wydaje się, iż problematykę efektów procesów transformacji i związanych z nimi zmian zachowań przedsiębiorstw przemysłowych na polu badań geografii przemysłu 
należy podejmować z jednej strony w zakresie oddziaływania poszczególnych elementów przestrzeni geograficznej na przedsiębiorstwo przemysłowe czy cały przemysł, a z drugiej - określić wpływ przedsiębiorstwa przemysłowego czy przemysłu na poszczególne elementy środowiska. Porównując wzajemne relacje, trzeba poszukiwać nowych mierników określających efektywność, odnoszącą się do relacji przedsiębiorstwa czy przemysłu w stosunku np. do podłoża geologicznego, zasobów kapitałowych czy zasobów intelektualnych, ale także metod pomiaru syntetycznego ujęcia tego złożonego problemu. Wydaje się, że zarysowana propozycja otwiera nowe pola badawcze i podnosi ich wartość aplikacyjną dla polityki i gospodarki przestrzennej.

\section{Literatura}

Antoniewicz J.D., Kulikowski M. red. 2004, Uwarunkowania rozwoju przedsiębiorstw, Instytut Wiedzy SGH, Warszawa

Bojar B. 2001, Bezpośrednie inwestycje zagraniczne w obszarach słabo rozwiniętych, Wydawnictwo Naukowe PWN, Warszawa

Borowiecki R. red. 1999, Wyzwania rozwojowe a restrukturyzacja przedsiębiorstwa, AE, TNOiK, Kraków

Borowiecki R. red. 1998, Restrukturyzacja a poprawa efektywności gospodarowania w przedsiębiorstwie, AE, TNOiK, Kraków

Borowiecki R. red. 2000, Zarzqdzanie wiedzq a procesy restrukturyzacji i rozwoju przedsiębiorstw, AE, TNOiK, Kraków

Dobrowolska M. 1978, Procesy industrializacji i urbanizacji jako czynniki wzrostu i przemian struktury przestrzennej rejonu uprzemystawianego, [w:] Przemiany spoleczno-ekonomiczne Tarnobrzeskiego Rejonu Uprzemysławianego, red. Z. Zioło, PAN Komitet Badań Rejonów Uprzemysławianych, PWN, Warszawa

Domański B. 2001, Kapitał zagraniczny w przemyśle Polski. Prawidłowości rozmieszczenia, uwarunkowania $i$ skutki, UJ, Instytut Geografii i Gospodarki Przestrzennej, Kraków

Karpiński A. 1994, Spór o przyszłość przemystu światowego, Komitet Prognoz „Polska w XXI wieku”, Warszawa

Karpiński A., Paradysz S., Ziemiecki J. 1999, Zmiany struktury gospodarki w Polsce do 2010. Polska na tle Unii Europejskiej, Komitet Prognoz „Polska w XXI wieku”, Warszawa

Kudełko J. 1996, Miejsce inwestycji zagranicznych w gospodarce kraju, [w:] Wptyw procesów transformacji gospodarki narodowej na funkcjonowanie jednostek gospodarczych i uktadów przestrzennych, red. Z. Zioło, Komisja Geografii Przemysłu PTG w Warszawie, Instytut Geografii WSP w Krakowie, Warszawa-Kraków

Kudełko J. 1997, Uwarunkowania prawne inwestycji zagranicznych w Polsce, [w:] Problemy transformacji struktur przemystowych $w$ procesie przechodzenia do gospodarki rynkowej, red. Z. Zioło, Komisja Geografii Przemysłu PTG w Warszawie, Instytut Geografii WSP w Krakowie, Warszawa-Kraków

Kudełko J. 2002, Poziom rozwoju gospodarczego województwa podkarpackiego w świetle produktu krajowego brutto w 1998 r., [w:] Problemy transformacji struktur regionalnych i konkurencyjność regionów w procesie integracji europejskiej, red. A. Klasik, Z. Zioło, WSIiZ, Rzeszów, s. $133-147$

Kudełko J. 2005, Rozwój regionalny a konkurencyjność regionów, [w:] Uwarunkowania rozwoju i konkurencyjności regionów, red. Z. Zioło, Instytut Gospodarki WSIiZ, Kraków-Rzeszów, s. 57-73

Kukliński A. red. 1995, Nauka-Technologia-Gospodarka, Komitet Badań Naukowych, Warszawa

Kukliński A. red. 2001, Gospodarka oparta na wiedzy. Wyzwanie dla Polski XXI wieku, Komitet Badań Naukowych, Warszawa 
Misztal S., Zioło Z. red. 1998, Dorobek polskiej geografii przemystu, Wydaw. Krakowskiego Oddziału PAN, Kraków

Olesiński Z. red. 1998, Bezpośrednie inwestycje zagraniczne w Polsce, PWE, Warszawa

Pakuła L., Troc M. 1987, Bibliografia geografii przemystu za lata 1963-1983, Wydawnictwo Naukowe WSP, Kraków

Rachwał T. 2005, „Funkcjonowanie przedsiębiorstw przemysłowych Polski Południowo-Wschodniej w procesie transformacji systemu gospodarowania", (rozprawa doktorska), Zakład Przedsiębiorczości i Gospodarki Przestrzennej Instytutu Geografii Akademii Pedagogicznej w Krakowie, Kraków

Rachwał T. 2004, Restrukturyzacja przedsiębiorstw przemystowych Polski Poludniowo-Wschodniej jako warunek ich konkurencyjności na rynku Unii Europejskiej, [w:] Uwarunkowania rozwoju przedsiębiorstw, red. J.D. Antoniewicz, M. Kulikowski, Instytut Wiedzy SGH, Warszawa

Stabryła A. red. 2000, Strategia wzrostu produktywności firmy, AE, Kraków

Stryjakiewicz T. 1999, Adaptacja przestrzenna przemystu w Polsce w warunkach transformacji, UAM, Seria Geograficzna nr 61, Poznań

Zioło Z. 1972, Próba konstrukcji syntetycznej wielomiernikowej mapy przemystu, „Polski Przegląd Kartograficzny", t. 4, nr 3, s. 127-133

Zioło Z. 1973, Analiza struktury przestrzennej i form koncentracji przemystu województwa rzeszowskiego w świetle wybranych mierników, Folia Geographica, Series Geographica-Oeconomica, vol. VI, s. 95-116

Zioło Z. 1980, Wpływ przemystu na rozwój społeczno-ekonomiczny regionu rzeszowskiego, PAN Komitet Badań Rejonów Uprzemysławianych, PWN, Warszawa

Zioło Z. 1986, Modele przemian struktur przemystowych, [w:] Rozwój przemystu i przemiany struktury przestrzenno-gatęziowej województwa bielskiego w latach 1975-1985, WUS, Bielsko-Biała, s. $10-13$

Zioło Z. 1996, Model funkcjonowania przestrzeni geograficznej i jego znaczenie dla gospodarki przestrzennej, [w:] Gospodarka, przestrzeń, środowisko, red. U. Wich, UMCS w Lublinie, pod patronatem PAN Komitetu Przestrzennego Zagospodarowania Kraju, Lublin, s. 183-191

Zioło Z. 1997, Miejsce struktury przestrzennej przemystu w przestrzeni geograficznej, [w:] GeografiaCzłowiek - Gospodarka. Profesorowi Bronisławowi Kortusowi w 70. rocznicę urodzin, Kraków, s. $125-132$

Zioło Z. 1999, Model funkcjonowania przestrzeni geograficznej jako próba integracji badań geograficznych, [w:] Geografia na przełomie wieków - jedność w różnorodności, Wydział Geografii i Studiów Regionalnych Uniwersytetu Warszawskiego, Warszawa, s. 122-131

Zioło Z. 2001, Informatyzacja przestrzeni gospodarczej jako wyznacznik konkurencyjności regio$n u$, [w:] Konkurencyjność miast i regionów a przedsiębiorczość i przemiany strukturalne, red. A. Klasik, Prace naukowe AE w Katowicach, Katowice

Zioło Z. 2004, Ksztaltowanie się firm informatycznych jako nowych elementów struktury przestrzennej przemystu, [w:] Przemiany struktur przemystowych, red. Z. Zioło, Z. Makieła, Prace Komisji Geografii Przemysłu, nr 7, Warszawa-Kraków, s. 97-106

Zioło Z. red. 1988, Zakład przemystowy w akademickim ksztatceniu nauczycieli, Materiały i Sprawozdania COMSN, nr 16, Wydawnictwo Naukowe WSP, Kraków

Zioło Z. red. 1990, Problematyka ośrodka przemysłowego w akademickim kształceniu nauczycieli geografii, Materiały i Sprawozdania COMSN, nr 19, Wydawnictwo Naukowe WSP, Kraków

Zioło Z. red. 1993, Problematyka okręu przemysłowego w akademickim kształceniu nauczycieli geografii, Materiały i Sprawozdania COMSN, nr 26, Komisja Geografii Przemysłu PTG, Wydawnictwo Naukowe WSP, Kraków

Zioło Z. red. 1993, Regionalne problemy uprzemystowienia, Materiały i Sprawozdania COMSN, nr 27, Komisja Geografii Przemysłu PTG, Wydawnictwo Naukowe WSP, Kraków 
Zioło Z., red. 1996, Wpływ procesów transformacji gospodarki narodowej na funkcjonowanie jednostek gospodarczych i układów przestrzennych, Komisja Geografii Przemysłu PTG w Warszawie, Instytut Geografii WSP w Krakowie, Warszawa-Kraków

\section{Research problems concerning the effects of the Polish industrial space restructurisation}

The article presents the basic research problems concerning the country's industrial space transformation processes. Special attention is paid to the changes in the activity of industrial enterprises, which are treated as an element of the varied forms of spatial concentration of industry and industrial space, to the influence of the European integration on the changes in the conditions of industry development, and to the new measures of the industrial activity, crucial in the industrial geography research. 